\section{Edycascão
Por, Escrito}

EDITORIAL

\section{Editores}

Maria Inês Côrte Vitoria PUCRS, RS, Brasil Pricila Kohls dos Santos PUCRS, RS, Brasil

\section{Equipe Editorial}

Carla Spagnolo PUCRS, Brasil Rosa Maria Rigo PUCRS, Brasil

\section{ISSN 2179-8435}

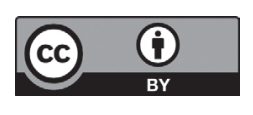

Este artigo está licenciado sob forma de uma licença Creative Commons Atribuição 4.0 Internacional, que permite uso irrestrito, distribuição e reproduçáo
em qualquer meio, desde que a publicaçăo origina seja corretamente, citada. http://creativecommons.org/licenses/by/4.0/deed.pt_BP
$\mathrm{T}$ Temos em mãos a primeira edição de 2018 da Revista Educação Por Escrito e com satisfação apresentamos os artigos que compõe a edição.

O primeiro artigo a compor a referida edição está intitulado "Diversidade na formação inicial de professores: Experiências do cotidiano escolar no PIBID" de autoria de Fabrício Oliveira da Silva, Joana Maria Leôncio Núñez e Jane Adriana Vasconcelos Pacheco Rios. O mesmo tem o objetivo de apresentar a análise das compreensões de licenciandos de Pedagogia e de Ciências Sociais na iniciação à docência, considerando suas vivências no subprojeto interdisciplinar: "Diversidade e Docência na Educação Básica", resultando na análise dos estudantes ancoda numa perspectiva de entendimento intercultural sobre a diversidade, levando em consideração a realidade dos estudantes da escola básica.

O segundo artigo, de autoria de Ana Paula Quevedo Peil e Angela Dillmann Nunes Bicca, tem como título "Problematizando discursos educacionais críticos em Meu Professor é o Cara", e uma análise ao problematizar alguns elementos dos discursos educacionais acionados de forma recorrente no quadro Meu professor é o cara, integrante do programa de televisão COMO SERÁ?, fazendo uma intersecção com diferentes autores da área da Educação, tais como Freire, Garcia, Tardif, dentre outros.

O terceiro texto de autoria de Altair Alberto Favero, Carina Tonieto e Bianca Possel aborda a "A resolução de problemas como prática interdisciplinar na educação: uma proposta epistemetodológica". Nesse trabalho, os autores apresentam a resolução de problemas como uma possibilidade de prática interdisciplinar a partir de uma concepção epistemetodológica, buscando pensar alternativas metodológicas que tornem possível a experimentação da interdisciplinaridade no contexto escolar/acadêmico.

O quarto artigo intitula-se "Diálogos em roda: contribuições para a formação de educadores e educandos na educação formal e não formal", de autoria de Maria Elisabete Machado e Ana Lúcia Souza de Freitas. Nesse trabalho, as autoras buscaram, a partir dos diálogos em roda, a compreensão acerca do potencial formativo do pensamento freireano para orientar a reflexão sobre a prática, tendo em vista constituir processos educativos emancipatórios, tanto para os educandos quanto para os educadores e educadoras.

O quinto artigo intitulado "A leitura de contos como recurso didático para a formação do leitor em clube do livro a partir da pedagogia histórico-crítica" de autoria de Karla 
Raphaella Costa Pereira, Maycon Maia Rodrigues e Frederico Jorge Ferreira Costa apresenta uma pesquisa ação relacionada PIBID por meio do projeto Clube do Livro, apresentando como principal resultado a oportunidade de oferecer aos educandos instrumentalização para o acesso a obras literárias de qualidade, além da reflexão baseada na pedagogia histórico-crítica.

Já o sexto artigo de autoria de Marilia Salles Bastos e Luciana Dalla Nora dos Santos sob o título "Concepções e práticas acerca da formação continuada e o papel da gestão escolar: narrativas de professoras" apresenta as concepções de professoras sobre formação continuada e o modo como a gestão encaminha essas atividades. Salientando o papel da gestão ao possibilitar e considerar espaços para escuta, reflexão e compartilhamento de experiências como base para o planejamento pedagógico.

O sétimo artigo intitulado "Repercussão da área específica de conhecimento na constituição e expressividade docente" de autoria de Mirian Haubold Barbosa, Silvia Maria de Aguiar Isaia e Claudia Terezinha Quadros se propõe a compreender de que maneira e em que medida o conhecimento específico interfere na construção da trajetória docente, na elaboração do saber acadêmico e no exercício da atividade formativa.

O oitavo e último artigo "Inovação Curricular: um desafio possível" de autoria de Fernando Degrandis e Cíntia Bueno Marques apresenta um projeto de reestruturação curricular apresentado como um desafio estratégico à uma rede de escolas particulares de Porto Alegre, além de reflexões acerca da temática das inovações curriculares em contextos de educação básica.

O artigo que fecha esta edição, de autoria de Larici Keli Rocha Moreira, Laine Rocha Moreira e Marta Genú Soares, intitulado "Educação Superior no Brasil: discussões e reflexões" apresenta uma reflexão histórica sobre o desenvolvimento da Educação Superior no Brasil e os aspectos que a constituíram.

Aos leitores, desejamos uma ótima e agradável viagem de leitura pelos textos da nossa revista Educação Por Escrito! 